\title{
The Incubation and Hatching Patterns of the Rufous Vanga
}

\author{
Kazuhiro Eguchi* and Satoshi Yamagishi** 1)
}

\begin{abstract}
We provide information on the onset of incubation, the involvement of males and females in incubation, and on the hatching pattern in the Rufous Vanga Schetba rufa of Madagascar. Rufous Vangas breed cooperatively with one to four one-year-old and/or adult auxiliary males. Large amounts of time were spent in incubation from the date the first-egg was laid. Breeding male Rufous Vangas took a much greater share of incubation during the laying period than did females, but males and females took almost equal shares during the incubation period. Females spent more time brooding their chicks than did males, however, males contributed more in terms of provisioning young chicks than did females. While the hatching pattern varied from perfectly asynchronous to perfectly synchronous, the fledging pattern was generally synchronous with all chicks in a given brood fledging on the same day. The nest failure hypothesis cannot explain the adaptive significance of early commencement of incubation in this species, because the incubation pattern was not a reliable predictor of the hatching pattern. As the daily ambient temperatures fluctuates greatly from $20^{\circ} \mathrm{C}$ to more than $35^{\circ} \mathrm{C}$, it is likely that Rufous Vangas commence incubation on the day on which the first egg is laid in order to regulate egg temperature and to increase the hatchability of first-laid eggs. Males may take charge of incubation during the laying period because females must spend considerable time foraging in order to produce eggs. Dominant males, in cooperatively breeding groups, may spend considerable time incubating, despite the risk of cuckoldry by auxiliary males, in order to raise the rate of hatchability.
\end{abstract}

Key words: Asynchronous hatching, Early incubation, Madagascar, Rufous Vanga, Schetba rufa.

キーワード：非同時孵化，早い抱卵開始，マダガスカル，アカオオ八シモズ.

\section{Introduction}

Among birds, embryonic development begins when eggs are warmed above a threshold temperature ("physiological zero") of about $28^{\circ} \mathrm{C}$ (Stoleson \& Beissinger 1995). To achieve this requires considerable time spent. Most birds lay one egg daily. If parent birds start incubation before clutch completion, variation in embryo development may occur within a clutch and, then, eggs may hatch asynchronously over a spread of a several days. On the other hand, if parents start incubation after clutch completion, hatching may be synchronous. Parents can, therefore, manipulate the onset of embryo development and to a certain extent control hatching intervals, by controlling the onset of incubation adaptively to increase their fitness. Asynchronous hatching is seen among various avian taxa (e.g., raptors, herons and many passerines) as often as synchronous hatching (Clark \&

Received 6 October 2001, Revised 16 July 2002, Accepted 26 August 2002.

* Department of Biology, Faculty of Science, Kyushu University, Fukuoka 812-8581, Japan.

** Department of Zoology, Faculty of Science, Kyoto University, Kyoto 606-8502, Japan.

1) Present address: Yamashina Institute for Ornithology, 115 Konoyama, Abiko City, Chiba 270-1145, Japan. 
Wilson 1981, Slagsvold 1986, Stoleson \& Beissinger 1995).

Hitherto, many hypotheses have been proposed to explain the selective significance of hatching pattern. Stoleson \& Beissinger (1995), for example, reviewed 17 different relevant hypotheses. While hypotheses abound to explain such patterns, empirical data on hatching patterns are scarce, in particular, data on the onset of incubation and the contribution to incubation by both sexes are few (Stoleson \& Beissinger 1995). Here, we provide data on the relative contributions of males and females to the incubation of clutches from the date of first egg laying to hatching in the Rufous Vanga Schetba rufa in Madagascar.

The Rufous Vanga is endemic to Madagascar (Langrand 1990). Recently, its breeding biology has been clarified by Yamagishi et al. (1995), Eguchi et al. (2001), and Eguchi et al. (2002), who have confirmed that it is a cooperative breeder. Although the Rufous Vanga breeds monogamously, some monogamous pairs are accompanied by one or more one-year-old males or adult males, or both. Some of these auxiliary males help breeding pairs mainly by participating in anti-predator defence, in territorial defence, or in provisioning chicks (Eguchi et al. 2002). Although one-year-old males are sexually immature, males of two years or older are mature (Yamagishi et al. 2002). In most breeding groups, auxiliary males are the sons of the breeding pair, however, as adult females often change territories, auxiliary males are often unrelated to the breeding females they are assisting (Eguchi et al. 2002). In groups with auxiliary males, paired males are dominant over auxiliary males, but adult auxiliary males often follow breeding females and, sometimes, copulate with them (pers. obs.). Because females are fertile during the laying stage, dominant paired males should guard their mates from other males, by continuously following their mates, or otherwise risk their infidelity (Birkhead \& Møller 1992). The presence of sexually mature auxiliary males in a breeding group may affect the pattern of incubation behaviour of breeding males, such as the onset of, or participation in, incubation.

In this paper, we provide information on patterns of onset of incubation, hatching and fledging, and on shared incubation between male and female Rufous Vangas. Particularly, we show that dominant males spent a large amount of their time incubating during the egg-laying period despite the associated greater risk of cuckoldry by auxiliary adult males. We also discuss the significance of early incubation by males.

\section{Methods}

The study was conducted in a deciduous dry forest, with many 2-5 m wide trails, at the Ampijoroa Forest Station $\left(16^{\circ} 15^{\prime} \mathrm{S}, 46^{\circ} 48^{\prime} \mathrm{E}\right)$, Ankarafantsika Strict Nature Reserve, about $110 \mathrm{~km}$ southeast of Mahajanga. The study area has previously been described in detail by Eguchi et al. (2002). The climate in the area is tropical with a six month dry season from May to October followed by a six month wet season from November to April. Daily maximum ambient temperatures often exceed $35^{\circ} \mathrm{C}$, while the minimum temperature during the breeding season is around $20^{\circ} \mathrm{C}$ (Asai et al. 2002).

Data used in this paper were collected in the course of a study on social structure and cooperative breeding of the Rufous Vanga. The study was conducted from 1994 to 1997, 
from October to December in 1994, and in other years, from August or September to January. In advance of observation, birds were caught in mist nets, measured, and ringed with unique combinations of coloured plastic and numbered aluminium rings. Numbers of banded birds are as follows; 34 (83\% of the studied population), $78(74 \%), 88(85 \%)$ and $123(90 \%)$ for 1994, 1995, 1996 and 1997, respectively. Because adult Rufous Vangas have sexually dimorphic plumage and one-year-old males of female-like plumage have a spotted-throat (Yamagishi et al. 2002), they were easily discriminated in the field. On-year-old females have buff tips on the greater wing coverts, which enabled us to discriminate them from older females in the hand.

Nest building starts in late September, and egg-laying in early October, and, if nest failure occurs, a replacement nest is built within a week of the failure (Eguchi et al. 2001). Nests are bowl-shaped and located on the first fork of trees about $4 \mathrm{~m}$ above the ground. By following individuals or groups, nests were easily found, and their location was then plotted on a map. Egg laying is confined to the three months from October to December. This species is single-brooded, and usually lays four eggs (Eguchi et al. 2001).

Once nest building had begun, each nest was checked every 5-7 days using a small mirror attached to a pole. During the egg laying period and around the expected date of hatching, nests were checked every day in order to confirm clutch size and brood size. Nests were also checked around the expected date of fledging, and fledglings were searched for. During the four year study period we found 202 nests. Eggs hatched in 87 of these nests, and offspring fledged from 46 of them, however, because we were not always able to collect a full set of data from each nest from laying to fledging, sample sizes differ among analyses. The number of hatchlings was confirmed at 72 nests, the hatching order of individual eggs was confirmed at 24 nests, and fledging dates were obtained from 16 nests.

Nest attendance, nest visiting frequency, and provisioning rate data were collected as follows. We conducted observations at nests for four hours from $06: 00$ to $10: 00$, in order to identify the individuals visiting, the food items brought, and to measure the amount of time spent in the nests. The activities of most pairs that were not supported by auxiliary birds, were recorded for three hours from $06: 00$ to $09: 00$, using automatic video cameras. Nest watches were primarily conducted in order to collect data on provisioning rates during our study of the helping behaviour of auxiliary birds, consequently few data was collected before hatching. Nests were selected at random for observation. Observations were restricted to the early mornings, because provisioning activity was high then. Ambient temperatures were highest in the afternoons in the study area, and high temperatures were thought likely to restrain the activity of the birds. It was considered likely, therefore, that bird activity around nests would be highest during the mornings. In total, we used data from nest watches conducted at 21 nests during the building stage, 31 nests during the laying stage, 51 nests during the incubation stage, and 61 nests during the nestling stage.

Data on the agonistic interactions between breeding males and auxiliary males were mainly collected during nest watches. Most data were based on events around. Because attacks by breeding males on auxiliary birds seldom occurred far from their nests (pers. 
obs.), we believe that we were able to record most agonistic interactions during nest watches. Additionally, the members of several pairs with auxiliary adult birds were tracked during the nest building and egg laying periods, and interactions between group members were recorded. During the nest building period eight groups were observed for an average of 900 minutes (240-2645 min); during the laying period 14 groups were observed for an average of 461 minutes (119-918 $\mathrm{min}$ ); during incubation 18 groups were observed for 638 minutes (240-1453 min), and during the nestling period 24 groups were observed for 790 minutes (221-1443 min).

Our primary interest was in the incubation behaviour of breeding males in groups containing sexually mature auxiliary males. Hence, we divided breeding groups into three categries; unaided pairs, groups including adult auxiliary males and those including only one-year-old auxiliary males. Then, we made comparisons of the proportion of time spent in nest attendance, of individual contributions to incubation, of nest visiting frequencies and provisioning rates between groups with adult auxiliaries and those without them. Some groups with adult auxiliary males included one-year old auxiliary males.

\section{Results}

\section{Incubation}

Incubation started just after the first egg was laid (Fig. 1). In total, parent vangas sat in their nests for over $60 \%$ of each observation period on the day on which first eggs were laid (day one), and incubation time reached nearly $80 \%$ of observation periods on day two (Fig. 1). The overall trends were similar in groups of different categories in spite of large fluctuations of incubation time in unaided pairs and pairs with only one-year auxiliary due to small sample sizes.

Males made greater contributions to incubation than females during the laying period (Fig. 2). On day one, most incubation was by males, and thereafter, the incubation time of males remained at a same level, $40-50 \%$ of observation times. In contrast, females

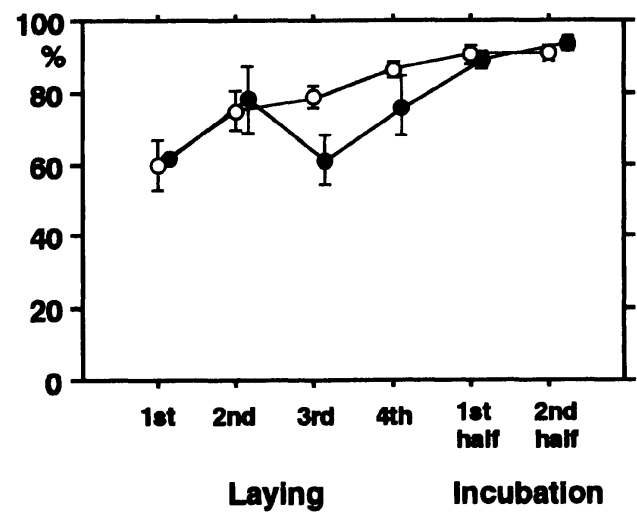

Fig. 1. Changes in the amount of time (\%) that Rufous Vangas sat on their nests during nest watches. Open circles $=$ pairs with adult auxiliary males. Closed circles $=$ unaided pairs and pairs with one-year-old males. Vertical bars indicate SE. 
contributed little to incubation at the start of the egg laying period (less than $20 \%$ of observation times), but, thereafter their time investment increased at about $40 \%$ of observation times. Trends were similar for females belonging to pairs of different categories, although values for females of pairs without adult auxiliary males during the laying stage fluctuated greatly due to small sample sizes (Fig. 2). Once clutches were complete, both sexes contributed equally to incubation. Auxiliary birds also visited nests, but remained only briefly (Fig. 2).

While dominant males were sitting on their nests, females were often observed being accompanied by, and being given food by, adult auxiliary males. Dominant males chased adult auxiliary males away from their females when they encountered them. Dominant males frequently attacked adult auxiliary males during the nest building and egg-laying periods (Fig. 3), however, dominant males did not guard their mates by continuous following.

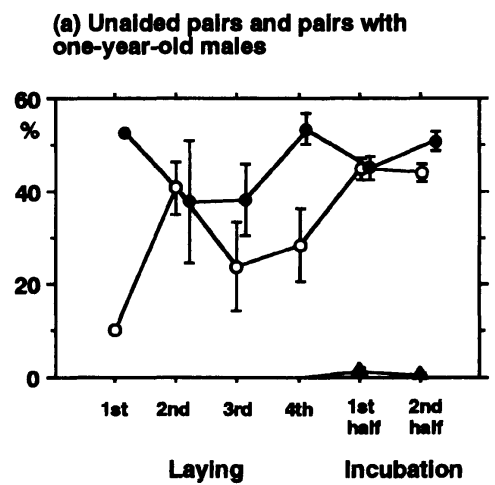

(b) Pairs with adult males

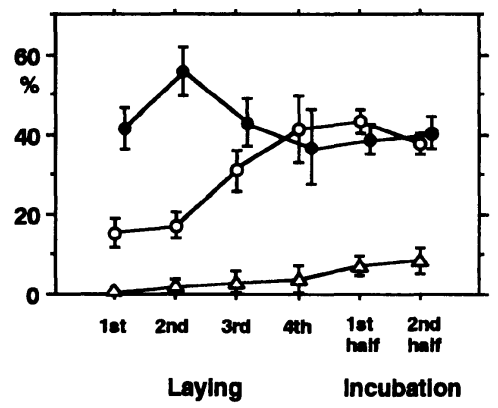

Fig. 2. Changes in the amount of time (\%) that individual Rufous Vangas sat on their nests during nest watches. Open circles $=$ breeding females. Closed circles $=$ dominant males. Open triangles $=$ adult auxiliary males. Closed triangles=one-year-old males. Data for one-year-old males in groups with adult auxiliary males are not shown because they did not visit nests. Vertical bars indicate SE. 


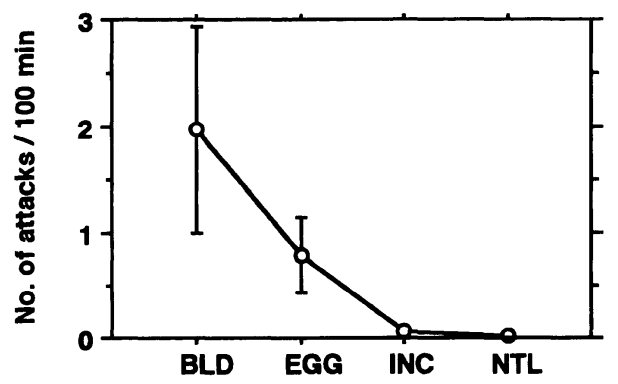

Fig. 3. The frequency of attacks on adult auxiliary males by dominant male Rufous Vangas. BLD= nest building stage. EGG $=$ egg-laying stage. $\quad \mathrm{INC}=$ incubation stage. $\mathrm{NTL}=$ nestling stage. Vertical bars indicate SE.

Table 1. Number of unhatched eggs.

\begin{tabular}{lrrrrr}
\hline & \multicolumn{4}{c}{ No. of unhatched eggs } & \multirow{2}{*}{ Total no. of nests } \\
\cline { 2 - 5 } Clutch size & 0 & 1 & 2 & 3 & \\
\hline 4 eggs & 23 & 26 & 8 & 1 & 58 \\
3 eggs & 9 & 4 & 1 & 0 & 14 \\
\hline
\end{tabular}

\section{Hatching}

Hatching success was low; many clutches included one or two unhatched eggs (Table 1). We confirmed the daily hatching pattern for 24 clutches (Table 2). Hatching occurred over periods of one, two or more days. On the first day of hatching, only one egg hatched in ten clutches, two eggs in nine clutches, three eggs in four clutches cases, and all four eggs in only one clutch. Of ten nests, in which the entire clutch hatched, one egg hatched on the first day in five nests and two or more eggs hatched on the first day in five nests (Table 2). Typical asynchronous hatching (in which one egg hatched each day) occurred in only five nests, while typical synchronous hatching (in which all eggs hatched in a single day) occurred in six nests. In many nests, however, the hatching pattern was of an intermediate type, with one egg hatching on one day and two or more eggs hatching on another day. Thus, the hatching pattern was variable.

The mean interval from clutch completion to the date of first egg hatching was 16.2 days (range $=14-19$ days; $n=62$ ), mostly 16 days. The hatching pattern was not related to the interval from clutch completion to first egg hatching (Table 2), thus the duration that eggs were in the nests was longer in asynchronously hatched broods ( 21.5 days \pm 0.97 , $n=16)$ than in synchronously hatched broods $(20.3$ days $\pm 1.37, n=6)$.

\section{Brooding and Provisioning of Young Chicks}

After hatching, parent vangas continued to brood their young for considerable periods of time. Even after Day 8, by when chicks had down and were able to self-thermoregulate, parents often remained standing on the edge of their nest, shading their chicks from direct solar radiation. Females spent more time attending their nests throughout the nestling stage, than males; significantly different between sexes in unaided pairs and in pairs with one-year-old males for broods of Day 8 or older (see Fig. 4). 
Table 2. Hatching pattern.

\begin{tabular}{|c|c|c|c|c|c|c|c|c|c|}
\hline \multirow{2}{*}{ Nest } & \multirow{2}{*}{ Breeding $^{1}$} & \multicolumn{4}{|c|}{ No. of hatchlings ${ }^{2}$} & \multirow{2}{*}{$\mathbf{B S}^{3}$} & \multirow{2}{*}{$\mathrm{CS}^{4}$} & \multirow{2}{*}{$\begin{array}{c}\text { Laying } \\
\text { date }\end{array}$} & \multirow{2}{*}{ MIP $^{5}$} \\
\hline & & Day 1 & Day 2 & Day 3 & Day 4 & & & & \\
\hline \multicolumn{10}{|l|}{1995} \\
\hline $\mathbf{H}$ & py & 1 & 2 & & & 3 & 3 & $10 / 9$ & 16 \\
\hline D & $\mathrm{pm}$ & 2 & $?$ & $?$ & $?$ & 4 & 4 & $10 / 13$ & 16 \\
\hline $\mathrm{Y}$ & py & 2 & & & & 2 & 3 & $10 / 22$ & 17 \\
\hline $\mathrm{C}$ & $\mathrm{pm}$ & 1 & 1 & 1 & & 3 & 4 & $10 / 22$ & 16 \\
\hline CX & py & 2 & 1 & & & 3 & 3 & $10 / 24$ & 18 \\
\hline $\mathrm{EX}$ & $\mathrm{p}$ & 2 & 1 & & & 3 & 4 & $10 / 25$ & 17 \\
\hline $\mathbf{E}$ & $\mathrm{p}$ & 1 & 2 & & & 3 & 4 & $10 / 26$ & 16 \\
\hline$T$ & $\mathrm{p}$ & 1 & 1 & 1 & 1 & 4 & 4 & $10 / 26$ & 17 \\
\hline F2 & $\mathrm{p}$ & 2 & 1 & & & 3 & 4 & $10 / 28$ & 16 \\
\hline G & $\mathrm{p}$ & 1 & 1 & 1 & & 3 & 4 & $10 / 28$ & 16 \\
\hline M2 & $\mathrm{p}$ & 1 & 2 & 1 & & 4 & 4 & $10 / 29$ & 16 \\
\hline $\mathrm{CC}$ & $\mathrm{p}$ & 1 & 1 & & & 2 & 3 & $11 / 1$ & 17 \\
\hline L & py & 2 & 1 & 1 & & 4 & 4 & $11 / 7$ & 16 \\
\hline $\mathrm{EE}$ & $\mathrm{p}$ & 2 & 1 & & & 3 & 3 & $11 / 9$ & 17 \\
\hline IX & $\mathrm{p}$ & 3 & & & & 3 & 4 & $11 / 23$ & 17 \\
\hline \multicolumn{10}{|l|}{1996} \\
\hline IX & $\mathrm{p}$ & 1 & 1 & & & 2 & 4 & $10 / 10$ & 16 \\
\hline $\mathrm{L}$ & $\mathrm{pm}$ & 3 & & & & 3 & 4 & $10 / 24$ & 16 \\
\hline $\mathbf{T}$ & $\mathrm{p}$ & 4 & & & & 4 & 4 & $10 / 25$ & 17 \\
\hline $\mathbf{M}$ & $\mathrm{p}$ & 2 & & & & 2 & 4 & $11 / 12$ & 18 \\
\hline \multicolumn{10}{|l|}{1997} \\
\hline $\mathrm{CX}$ & $p$ & 1 & 2 & 1 & & 4 & 4 & $10 / 22$ & 16 \\
\hline IX & $\mathrm{p}$ & 3 & & & & 3 & 4 & $10 / 27$ & 14 \\
\hline JX2 & py & 2 & 1 & & & 3 & 4 & $11 / 4$ & 16 \\
\hline $\mathrm{RX} 4$ & py & 1 & 2 & & & 3 & 3 & $12 / 10$ & 16 \\
\hline $\mathrm{T} 2$ & $\mathrm{p}$ & 3 & & & & 3 & 4 & $?$ & $?$ \\
\hline
\end{tabular}

${ }^{1}: \mathrm{p}=$ pairs without auxiliaries, $\mathrm{pm}=$ pairs with adult auxiliaries, $\mathrm{py}=$ pairs with one-year old auxiliaries.

2: ?= date of hatching was unknown.

3: $\mathrm{BS}=$ brood size.

4: $\mathrm{CS}=$ clutch size.

5: MIP (Minimum Incubation Period) = interval from clutch completion to first egg hatching.

Figure 5 shows the nest visiting rate and provision rate to chicks of Day 7 or younger. Among pairs unaided by auxiliary males, males visited their chicks (Days 1-7) significantly more times than did females $(P=0.013$, Wilcoxon signed-rank test). Among pairs with adult auxiliary males, males also visited their nests more frequently than females did, although the difference between the sexes was not significant $(P=0.099$, Wilcoxon signed-rank test). Males contributed more to provisioning their young chicks than did females, in both unaided pairs and in pairs with adult auxiliary males.

\section{Fledging Patterns}

The fledging pattern of the Rufous Vanga was confirmed in 16 nests (Table 3), in most of which all chicks fledged on the same day. The mean fledging period (from the hatching of the first egg to the fledging of the first chick was 14.8 days (range $=12-17$ 
(a) Unaided pairs

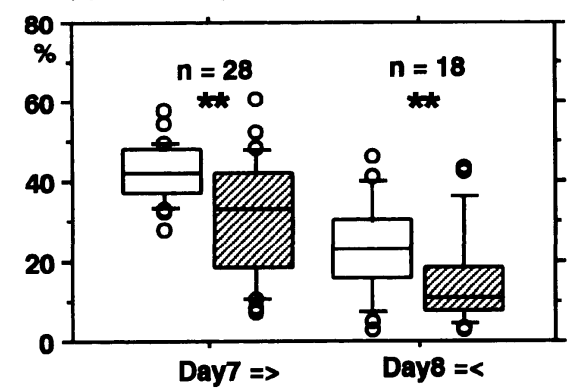

(b) Pairs with adult males

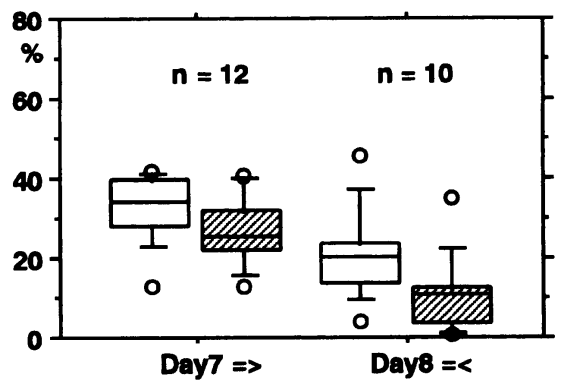

(c) Pairs with one-year-old males

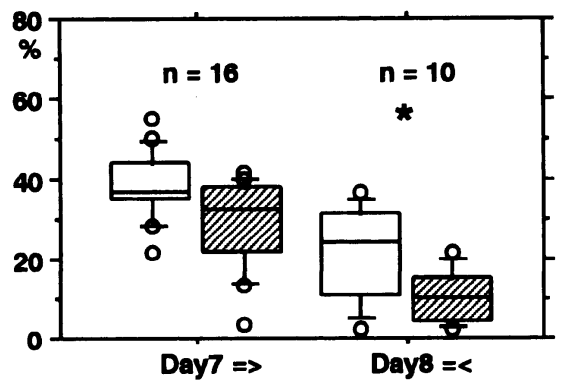

Fig. 4. Nest attendance by male and female Rufous Vangas during the nestling stage. Open boxes= females. Hatched boxes $=$ males. Horizontal bars indicate 10th, 25th, 50th, 75th, and 90th percentile ranges and plots are outliers. *: $P<0.05$, **: $P<0.01$; Wilcoxon signed-rank test.

days; $n=37$ ). When fledging, single broods included chicks at different developmental stages and, therefore, of different flying ability. Thus, although incubation was normally begun just after the first egg was laid, the hatching spread (even when asynchronous) was rather narrow, and fledging occurred synchronously.

\section{Discussion}

\section{Onset of Incubation and Hatching Pattern}

In the Rufous Vanga, the characteristics of incubation and hatching patterns were: 1) incubation commonly began with the first egg, 2) males shared in a greater part of 
incubation during the egg-laying period, 3) hatching pattern was variable (asynchronous, synchronous, or intermediate), but 4) fledging was rather synchronous.

Although incubation commonly began with the first egg, the resultant hatching pattern was varied. The duration between clutch completion and first egg hatching was relatively constant, commonly lasting 16 or 17 days. Therefore, for clutches hatching synchronously, first eggs were incubated 19 days and last eggs for 16 days; the difference in age among brood mates being three days at most. This observation contradicts the assumption that the duration from the onset of incubation to first hatching is constant,

(a) No. of visits/hour

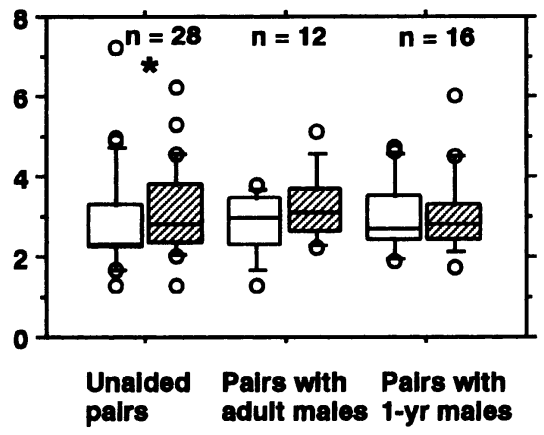

(b) No. of provisioning visits/hour

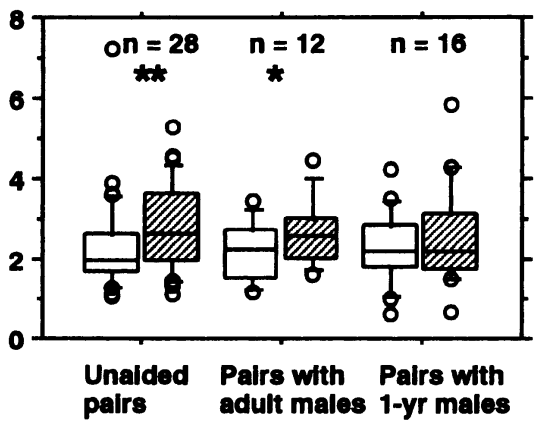

Fig. 5. The nest-visiting frequencies and provisioning rates of male and female Rufous Vangas until nestlings were seven days old. Open boxes $=$ females. Hatched boxes =males. ${ }^{*}: P<0.05,{ }^{* *}: P<$ 0.01; Wilcoxon signed-rank test (see Fig. 4 for plots).

Table 3. Fledging spread in individual Rufous Vanga broods.

\begin{tabular}{lllllll}
\hline \multirow{2}{*}{ No. of fledglings } & \multicolumn{4}{c}{ Fledging spread (days) } & \multirow{2}{*}{ Total no. of nests } \\
\cline { 2 - 6 } & 0 & 1 & 2 & 3 & 4 & \\
\hline 2 chicks & 2 & 1 & 0 & 1 & 0 & 4 \\
3 chicks & 6 & 0 & 0 & 0 & 1 & 7 \\
4 chicks & 2 & 2 & 1 & 0 & 0 & 5 \\
\hline
\end{tabular}


which is adapted in various models explaining hatching patterns (e.g. Clark \& Wilson 1981, Magrath 1990, Stoleson \& Beissinger 1995).

Despite incubation beginning with the first egg, and hatching pattern being variable, fledging was typically rather synchronous. Because the growth of individual chicks varied, the duration from hatching to fledging also varied between brood mates. Casual observations at nests in which synchronous fledging occurred, indicated that immature younger chicks fledged because they were stimulated by their older siblings. These facts suggest that incubation pattern is not a reliable predictor for either hatching pattern or fledging pattern.

The causes for the variability in hatching patterns among Rufous Vangas are not known. Embryonic development begins when eggs are warmed above physiological zero (Stoleson \& Beissinger 1995). We, therefore, suspect that initiation of embryonic development occurs independently of incubation in this species, however, because ambient temperatures may have differed among nests, embryonic development may not have started from the first egg in all clutches. Hatching patterns may vary among nests as a result of small differences in local ambient temperatures, and/or differences in the onset of incubation. We had only a few pairs in which data on both onset of incubation and hatching pattern were obtained.

\section{Adaptive Significance of Early Incubation}

Magrath (1990) and Stoleson \& Beissinger (1995) reviewed various hypotheses relating to the adaptive significance of early incubation. Among the hypotheses they considered, about two thirds were irrelevant to this study, because they concerned species in which: only females incubate, females initiate incubation, food supply declines sharply during the breeding season, brood reduction or sibling rivalry prevails, or nests are at great risk of brood parasitism. We consider three hypotheses here: 1) Nest failure hypothesis, 2) Egg viability hypothesis, and 3) Egg protection hypothesis.

The nest failure hypothesis deals with the duration that eggs or nestlings remain in a nest. Early incubation causes asynchronous hatching and fledging, while onset of incubation after clutch completion causes synchronous hatching and fledging. Species exhibiting asynchronous hatching will have shorter periods when the nest contains only eggs (compared with synchronous hatching) and the amount of time from first egg laying to the first chick fledging will also be shorter, but the total time that a nest contains nestlings will be greater (Stoleson \& Beissinger 1995). Hence, Clark \& Wilson (1981) suggested that greater predation during the nestling period favours synchronous hatching and that greater predation during the egg period favours asynchronous hatching. Murray (1994) demonstrated, using a mathematical model, that the probability that at least one chick will fledge is higher in asynchronously hatching broods, but the expected number of fledglings from a successful brood is smaller than in synchronously hatching broods. In the Rufous Vanga the hatching pattern was variable and fledging was rather synchronous, thus it is unlikely that parents began incubating early so as to reduce the time vulnerable to predation. Therefore, the nest failure hypothesis is not relevant to this species.

Stoleson \& Beissinger (1999) have reported that egg hatchability declines when eggs 
are left unincubated. If hatchability tends to be reduced in the unincubated first egg, then parents should initiate incubation when the first egg is laid. The egg viability hypothesis suggests that early incubation reduces the decline of egg hatchability. Eggs must be kept within a relatively narrow temperature range after initiation of embryonic development; high temperatures are generally more likely to prove fatal than low temperatures (Stoleson \& Beissinger 1995). In the House Sparrow Passer domesticus, the degree of hatching asynchrony increased in the latter half of the breeding season when ambient temperatures often exceeded physiological zero (Veiga 1992). In our Madagascan study area, maximum temperatures often exceed $35^{\circ} \mathrm{C}$ (well above physiological zero), and sunlight sometimes penetrates to nests during the daytime, while at night temperatures fall to about $20^{\circ} \mathrm{C}$. Strong direct solar radiation may raise egg temperatures above a fatal level. Morton \& Pereyra (1985) suggest that nest attendance will be longer in the mid-afternoon than at night in an environment where solar radiation is strong. High ambient temperature may initiate development of embryos even in the absence of incubation. Once embryonic development starts, parents must maintain egg temperature. In the Rufous Vanga, more than half of the clutches investigated included one or more unhatched eggs. The causes of hatching failure were unknown. However, if hatching failure derives from the death of embryos during the laying stage, it is advantageous for parents to start incubation from the date on which the first egg is laid. Parent Rufous Vangas, therefore, may begin incubation early in order to regulate egg temperature in an area experiencing high ambient temperatures and strong solar radiation. Further data on the causes of hatching failure and the relationship between laying order and hatchability would be helpful.

Koenig (1982) found that hatchability of eggs is lower in the tropics than in the temperate region. Koenig did not suggest a cause for this relationship, but Stoleson \& Beissinger (1999) attributed it to high ambient temperature in the tropics. Stoleson \& Beissinger (1999), by an experiment investigating hatchability of unincubated eggs and by interspecific comparison, demonstrated that the viability of unincubated eggs exposed to ambient temperatures was reduced, and that such a loss of viability was distinct in hot climates. They suggested that the initiation of embryonic development in unincubated eggs and exposure under inadequate temperature caused reduced viability. Viñuela \& Carrascal (1999), by a comparative study of hatching patterns, found that birds in the tropics start incubation earlier than those in temperate regions. They suggested that earlier onset of incubation in the tropics is to prevent reduced egg viability resulting from high ambient temperatures. Our findings for early onset of incubation and low hatchability support Viñuela \& Carrascal's (1999) conclusions.

Parent birds may begin incubation early in order to protect their eggs from interference and predation (Egg protection hypothesis). Rufous Vangas sat on their nests and incubated from the date on which the first egg was laid. Furthermore, attending parents chased almost all animals coming close to the nest. However, because protection of eggs is possible without incubation (Magrath 1990), if they stay at nests primarily for protection of eggs they need not sit on eggs. Egg protection, therefore, may be a derivative function from nest attendance for incubation. 


\section{Initiation by Males}

Male Rufous Vangas may take the initiative for starting incubation. During the egg-laying period, males spent much more time incubating than did females, although females increased the amount of time they spent incubating as laying progressed. In contrast to the Rufous Vanga, in many other species females both start incubation and invest more time in it (Haneda 1986, Stoleson \& Beissinger 1995). Most models of asynchronous hatching, therefore, assume that females take the major role in incubation (Clark \& Wilson 1981, Slagsvold \& Lifjeld 1989, Magrath 1990, Stoleson \& Beissinger 1995). Slagsvold \& Lifjeld (1989) suggested that there may be a sexual conflict over parental investment. According to them, in a species in which females take a greater part in incubation and brooding, females start incubation early in order that their eggs will hatch asynchronously and reduce the female's share in provisioning chicks during the first few days of the nestling stage. Slagsvold \& Lifjeld (1989) found that females rearing asynchronous broods were heavier than those rearing synchronous broods at the end of the nestling stage. Is there a reversed sexual situation in the Rufous Vanga? As mentioned earlier, early incubation is not a reliable predictor for hatching patterns in this species. Moreover, males contributed more to provisioning their young nestlings than did females, although the difference was only significant among unaided pairs. Therefore, it is unlikely that breeding males manipulated the onset of incubation in order to derive benefits from the consequences of subsequent hatching patterns.

If ambient temperatures exceed physiological zero, parents should sit on their nest from the day when the first egg is laid so as to regulate egg temperature. Females, however, must spend considerable time foraging in order to produce further eggs. Males ought, therefore, to choose to stay at the nest, or follow their females in order to prevent extra pair copulation by auxiliary males (Birkhead \& Møller 1992, Davies 1992). Because many nests included one or more unhatched eggs, the risk that embryos die in the course of laying and/or incubation may be high in this species. We observed copulation between auxiliary males and breeding females several times (pers. obs.), however, because the auxiliary males are usually the offspring of the breeding males (Eguchi et al. 2002), whereas they are usually unrelated to the breeding female, breeding males gain indirect benefits even when auxiliary males copulate with their stepmothers. Thus, breeding males should spend more time in incubation to increase hatchability than in defence of their mates.

\section{Acknowledgements}

We are grateful to the Government of the Republic of Madagascar for providing permission to conduct research in the Ankarafantsika Strict Nature Reserve, and to Dr Albert Randrianjafy, Director of Park Botanique et Zoologique de Tsimbazaza, and staff members J. R. Ramanampamonjy, H. Randriamahazo, F. Rakotondraparany, B. Raveloson and J. Razanatsoa, for their kind co-operation during the study. H. Nagata, T. Hino, T. Mizuta, M. Hotta, H. Kofuji, T. Masuda, M. Tanimura, F. Iwasaki, H. E. Amano, S. Fukushima, and Y. Takeda assisted in fieldwork. We also thank the staff of Conservation International for lodging and facilities at the Forest Station, and H. Matsukawa, of the 
Embassy of Japan, for his support. Dr Masaoki Takagi and an anonymous referee gave useful suggestions and comments on an earlier draft. Dr. Mark Brazil helped in English and gave valuable comments on our manuscript. This study was partly supported by a Grant-in-Aid from the Monbusho International Scientific Research Program (No. 06041093).

\section{References}

Asai, S., Mizuta, T., Eguchi, K. \& Yamagishi, S. 2002. Environmental cues that initiate reproduction in the Rufous Vanga (Schetba rufa). Journal of Yamashina Institute for Ornithology 34: 232-239.

Birkhead, T. R. \& Møller, A. P. 1992. Sperm Competition in Birds: Evolutionary Causes and Consequences. Academic Press, London.

Clark, A. B. \& Wilson, D. S. 1981. Avian breeding adaptations: hatching asynchrony, brood reduction, and nest failure. Quarterly Review of Biology 56: 253-277.

Davies, N. B. 1992. Dunnock Behaviour and Social Evolution. Oxford University Press, Oxford.

Eguchi, K., Nagata, H., Asai, S. \& Yamagishi, S. 2001. Nesting habits of the Rufous Vanga in Madagascar. Ostrich 72: 201-203.

Eguchi, K., Yamagishi, S., Asai, S., Nagata, H. \& Hino, T. 2002. Helping does not enhance reproductive success of cooperatively breeding Rufous Vanga in Madagascar. Journal of Animal Ecology 71: 123-130.

Haneda, K. (ed.) 1986. Life History of Birds. Tsukiji Shokan Press, Tokyo (in Japanese).

Koenig, W. D. 1982. Ecological and social factors affecting hatchability of eggs. Auk 99: 526-536.

Langrand, O. 1990. Guide to the Birds of Madagascar. Yale University Press, New Haven and London.

Magrath, R. D. 1990. Hatching asynchrony in altricial birds. Biological Review 65: 587-622.

Morton, M. L. \& Pereyra, M. E. 1985. The regulation of egg temperatures and attentiveness patterns in the Dusky Flycatcher (Empidonax oberholseri). Auk 102: 25-37.

Murray, B. G., Jr. 1994. Effect of selection for successful reproduction on hatching synchrony and asynchrony. Auk 111: 806-813.

Slagsvold, T. 1986. Hatching asynchrony: interspecific comparisons of altricial birds. American Naturalist 128: 120-125.

Slagsvold, T. \& Lifjeld, J. T. 1989. Hatching asynchrony in birds: the hypothesis of sexual conflict over parental investment. American Naturalist 134: 239-253.

Stoleson, S. H. \& Beissinger, S. R. 1995. Hatching asynchrony and the onset of incubation in birds, revisited: When is the critical period? In Current Ornithology vol. 12 pp. 191-270. (ed. Power, D.M.), Plenum Press, New York.

Stoleson, S. H. \& Beissinger, S. R. 1999. Egg viability as a constraint on hatching synchrony at high ambient temperatures. Journal of Animal Ecology 68: 951-962.

Veiga, J. P. 1992. Hatching asynchrony in the House Sparrow: a test of the egg-viability hypothesis. American Naturalist 139: 669-675.

Viñuela, J. \& Carrascal, L. M. 1999. Hatching patterns in altricial birds: a preliminary comparative analysis. In Proceedings of the 22nd International Ornithological Congress (eds. Adams, N. \& Slotow, R.), University of Natal, Durban.

Yamagishi, S. Asai, S., Eguchi, K. \& Wada, M. 2002. Spotted-throat individuals of Rufous Vanga Schetba rufa are yearling males and presumably sterile. Ornithological Science 1: 95-100.

Yamagishi, S., Urano, E. \& Eguchi, K. 1995. Group composition and contributions to breeding by Rufous Vangas Schetba rufa. Ibis 137: 157-161.

\section{アカオオハシモズの抱卵開始と孵化のパターン}

マダガスカル固有種アカオオハシモズの抱卵行動の特徴と卵の孵化パターンを明らかにし, 
その適応的意義について考察した。調査は 1994 年〜1997 年の繁殖期（9月〜1月）にマダガス カル西部のアンピジュルア研究林の落葉広葉樹林で行った。調査地は 6 力月毎の雨期と乾期が はっきりと分かれ, 本格的降雨は 11 月後半に始まり, 日最高気温は 35 度を超え, 日最低気温 は 20 度付近まで下がる。

アカオオ八シモズは一夫一妻で繁殖するが，1歳以上の雄がつがいの繁殖を手助けする協同 繁殖種として知られている。2 歳以上の付加雄には繁殖能力があり, 繁殖雌との交尾も観察さ れている。繁殖は年 1 回のみで, 失敗した場合にはやり直し繁殖を行う。産卵数は大部分が 4 卵で, 半数以上の巣で 1 3 卵の未捊化卵が生じた。

抱卵は第 1 卵産卵後に始まり，巣毎の平均抱卵時間は観察時間の $60 \%$ 以上を占めた。第 1 卵産卵直後は雄の分担割合が大きく, 雌の分担割合は第 3 卵産卵後から増加し, 全卵産卵終了 後には雌雄の分担割合はほぼ等しくなった。産卵期における雌雄の抱卵分担は，2 歳以上の付 加雄のいるつがいでも，いないつがいでも同様の傾向を示した。造巣期や産卵期には, 繁殖雄 は 2 歳以上の付加雄に対して攻撃的であるが, 産卵期に雌につきまとって, 付加雄の接近を未 然に防ぐなどの行動は見られなかった。

孵化のパターンは巣により大きく異なり, 全卵が単一日に孵化する完全同時孵化と, 各卵が 毎日順次卯孚化する完全非同時孵化と, 両者の中間的なパターンが同程度に生じていた。巣立ち に際しては, 1 日でヒナ全部が巣を離れることが多く,このため, 若いヒナは兄弟に比べて未成 長の状態で巣立っていた。

従来提唱されている仮説 (Clark \& Wilson 1981, Magrath 1990) では, 早い抱卵開始は非同時 卯孚化を生じ, 非同時捊化は捕食回避や七ナの成長段階の階層化による餌不足への対処などの適 応的意義を持っとされている。しかし，アカオオ八シモズの場合は, 早い抱卵開始によっても,

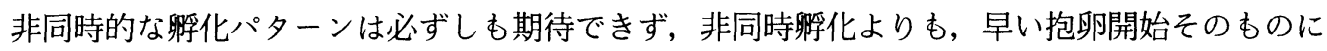
適応的な意義があると考えられた。調查地では最高気温が高く，気温の日較差が大きい。この ため, 抱卵なしでも発育ゼ口点を超え肧の成長を開始させる可能性が高く, 親は抱卵温度を一 定に保つために第 1 卵から抱卵する必要があると考えられる。また，直射日光により，卵が異 常高温にさらされることを防いだり，他の動物による巣への干渉を防ぐなど，卵を保護するた めにも第 1 卵からの抱卵は有用であると考えられる。

アカオオハシモズの抱卵のもう一つの特徵は, 抱卵開始時の雄による分担割合が大きいこ之 である。協同繁殖つがいの場合は, 雄は付加雄による繁殖雌のつがい外交尾の危険があるにあ 関わらず，第 1 卵から長時間抱卵し，積極的なメイトガードを行わない。未倠化卵を含む巣が 多いことから, 卵の死亡が多いことが示唆される。早い抱卵開始によって卵の死亡の多くが未 然に防げるのであれば，雌雄どちらかによる早い時期の抱卵は選択的な意義がある。雌は卵生 産のために採餌に多くの時間を必要とするならば，雄が産卵期に抱卵の多くを担うことにな る。付加雄のほとんどは繁殖雄の仔であり，たとえ付加雄と継母の繁殖雌との間でつがい外交 尾が生じても，繁殖雄にとっては間接的な利益を享受できると考えることができる。

江口和洋：九州大学大学院理学研究院生物科学部門. $=$ \% 812-8581 福岡市東区箱崎 6-10-1. E-mail: kegucscb@mbox.nc.kyushu-u.ac.jp

山岸 哲: 京都大学大学院理学研究科動物学教室. 干606-8502 京都市左京区北白川追分町. 現所属：(財)山階鳥類研究所. 千葉県我孫子市高野山 115. 